\title{
The Influence Of Word-Of-Mouth Online And Celebrity Endorser On Attitudes And Intentions Of Tourists To Visit Indonesia During The Covid-19 Pandemic
}

\author{
Lin Yan Syah ${ }^{1}$, Dedi Rianto Rahadi², M. Miftah Farid ${ }^{3}$
}

\author{
STIE Serelo Lahat Post Graduate Program ${ }^{1}$, President University ${ }^{2}$, \\ UIN Raden Fatah ${ }^{3}$ \\ Email: linyansyah@gmail.com,dedi1968@president.ac.id, \\ mmiftahfarid_uin@radenfatah.ac.id,
}

Received: August $6^{\text {th }} 2021$

Approved: November $1^{\text {st }} 2021$

\begin{abstract}
During the COVID-19 pandemic, many community activities were restricted, including visiting tourist destinations. This policy has an impact on the management of tourist areas experiencing losses. This study aims to examine the effect of electronic word of mouth (e-WOM), Celebrity Endorser, on the attitudes and intentions of tourists to visit West Java, Indonesia. Collecting data using a questionnaire with a sample of 180 respondents with convenience sample method The technique of data analysis using Structural Equation Modeling (SEM) of a statistical software package AMOS version 24. The conclusion from hypothesis The results show (1) e-WOM has no significant effect on tourist attitudes, (2) e-WOM has a significant effect on the intention to visit tourists. (3) celebrity endorser has a significant effect on tourist attitudes. (4) celebrity endorser has a significant effect on intentions to visit tourist attractions, (5) tourist attitudes have no significant effect on intentions to visit tourist attractions. The COVID-19 pandemic has become a momentum and taken into consideration to implement Virtual Reality Tourism as a solution before tourists decide to make a tourist visit.
\end{abstract}

Key words: electronic word of mouth, Celebrity Endorser, attitudes and intentions of tourists to make tourist visits

\section{Introduction}

In Indonesia, the sectors affected during the COVID-19 pandemic are transportation, tourism, trade, and other sectors, but the economic sector most affected by COVID-19 is the household sector (Susilawati et al., 2020). According to (OECD. 2020; Febrantara., 2020), the business sectors significantly impact tourism and transportation.

Tourism is one of the sectors most affected by the COVID-19 pandemic. This condition has brought about extraordinary changes and transformations in the planning and management of tourist destinations. Most destination organizations have changed their traditional business models to keep pace with the evolution of new technologies, emerging innovative advertising strategies, changing consumer markets, and increasing global competition (Formica and Kothari 2008).

Based on BPS data (2021), there was a significant decrease in the number of local and foreign tourists. 
Total foreign tourist visits to Indonesia in 2020 amounted to 4.02 million visits. When compared to 2019 , the number of foreign tourists decreased by 75.03 percent. The decline in tourists can be shown in the following graph:

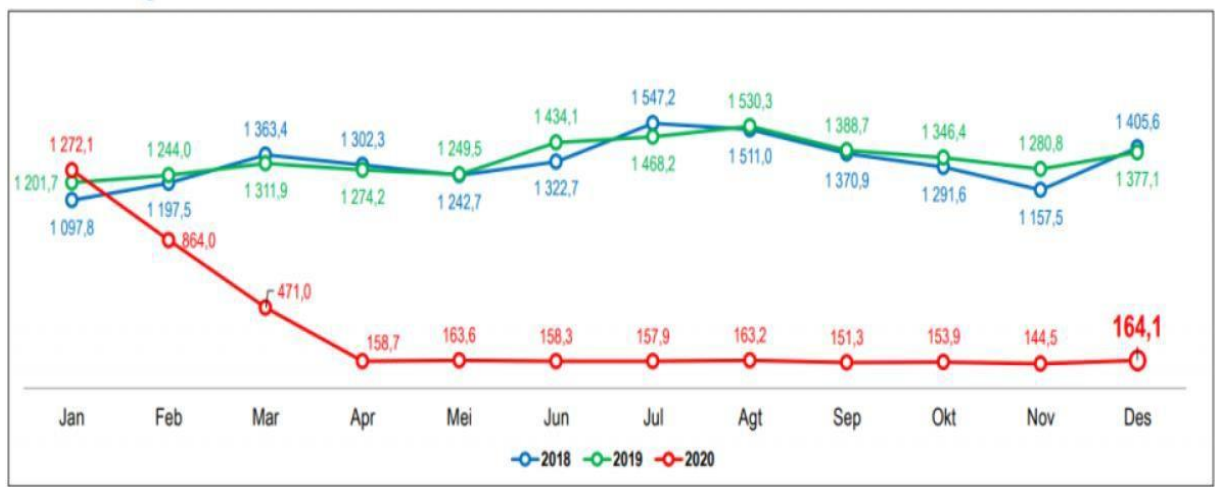

Graph 1 Tourist visits 2018 to 2020 (in thousands)

In 2018 tourist visits amounted to 1,405 million tourists. In 2019, it decreased to 1,377 million tourists, and in 2020 experienced a very high decline to 164 thousand tourists. The data shows the impact of the COVID-19 pandemic has reduced the number of tourist visits to various tourist visits. The impact of the government's policy of closing the tourism sector is to reduce the spread of COVID-19, maintain health, and reduce the death rate of the community.

The number of local tourists also decreased by 61 percent when compared to the previous year. The significant decline in the number of tourists has greatly affected the condition of the economy and tourism actors because tourism plays an essential role in increasing regional and state income and employment. The COVID-19 pandemic also threatens 13 million workers in the tourism sector and 32.5 million indirectly related to the tourism sector. (BPS, 2020).

Research on the impact of tourism has focused on the components of economic improvement, Mings, (1969). Deasy and Griess, 1966); Elkan, (1975); Sadler and Archer, (1975); Gunn, (1977). The study results are based on the fact that tourism activities have a significant, measurable economic improvement impact for the community, local government, and tourist site managers.

According to $\mathrm{Li}$ (2008), risk perception becomes a consideration in the initial assessment of the impact of the tourism sector crisis. The impact of these risks is quite significant during the COVID-19 pandemic, which causes public health conditions, behavior, and tourist preferences in emergencies.

The researcher's question is how to increase tourist visits while maintaining health protocols so that the economic sector runs during the COVID-19 pandemic. A pandemic makes tourists afraid to visit tourist attractions even though the manager has implemented suitable health protocols. One way to increase tourist visits can be through electronic Word Of Mouth (e-WOM) and celebrity endorsers to inform the condition of tourist attractions that have followed health protocols. Reduced consumer trust, both in organizations and in advertising, has caused electronic word of mouth (e-WOM) to become an option and become a competitive advantage and has relevance to tourism, especially tourist attitudes towards these destinations.

The development of information technology (internet) has become a medium in conveying Word Mouth communication. This tren is the beginning of the emergence of the term electronic Word of Mouth 
(eWOM.). eWOM can provide negative or positive statements written by netizens, potential or previous consumers about products or companies where this information is available to people or institutions via social media (Semuel \& Lianto, 2014). During the COVID-19 pandemic, the use of the internet to support community activities, including social media, is increasing. Activities that were previously faced in dealing with customers and producers have now been carried out virtually (online). People use social media a lot to convey good and bad experiences. According to Gretzel and Yoo (2008), more than seventy percent of tourists consider online testimonials from experienced tourists as the primary source of information when potential tourists decide to go abroad for a trip. Forrester Research (2006) also approved this statement, which states that online WOM is a crucial player for tourists. The delivery of messages through electronic word of mouth, where the public or consumers have an excellent opportunity to share information about their consumption experiences and disseminate it. Information about products and brands uses social networking platforms and consumer review sites (Godes and Mayzlin, 2004; Brown et al., 2007; Xia and Bechwati, 2008), which convey and collect pre-purchase information (Adjei et al., 2009). : Zhu and Zhang, 2010; Lee and Koo, 2012), and convey and direct consumer attitudes (Lee et al., 2009, Jalilvand et al., 2012), as well as an intention to buy products and services (Lin et al. al., 2013; Torlak et al., 2014, Charo et al., 2015; Ladhari and Michaud, 2015). With the increase in information on tourist attractions that have followed the health protocols delivered through e-WOM, it is hoped that it can lead to changes in tourist attitudes, ultimately leading to tourists' intentions to visit tourist places.

In addition to using e-WOM, the use of well-known celebrity endorsers or public figures to explain the conditions of healthy tourist sites can lead to changes in tourist attitudes, ultimately leading to tourists' intentions to visit tourist sites. Utilizing celebrities to promote products or services has been a centuryold phenomenon (Erdogan, 1999). Being a celebrity endorser who has been known to the public is used by marketers to promote products, services, and ideas (Park and Yim, 2020; Schimmelpfennig andnHunt, 2020). Marketers engaged in tourism destinations have joined the bandwagon and use celebrities to promote their destinations to domestic and international tourists. The celebrities become tourism ambassadors to introduce tourist attractions and attract tourists to visit, and this is often the highlight of marketing campaigns (van der Veen and Song, 2010). Celebrity endorsers can play an important role and ability in directing goals and having attitudes and interests to take the next journey (Teng \& Chen, 2020).

Information submitted by Celebrity endorsers can be through e-WOM, advertisements, or other media, which is expected to influence the attitudes and intentions of potential tourists to visit tourist attractions. Buying interest or making a tourist visit is one of the psychological aspects that has a large enough influence on consumer behavior. When tourists realize that a visit is necessary to reduce boredom at home, they will intend to make a tourist visit.

Research in tourism shows the positive and negative influence of e-WOM on tourism products in studies in various countries. Among them, research conducted by Wibisono and Martini (2016) states that celebrity endorsers positively affect purchase intention or make tourist visits. On the other hand, Balabanis (2016) states that celebrity endorsers harm tourist visits. Research by New Zealand-based Morgan, Pritchard, and Piggott (2003) suggests that negative eWOM can have a tremendous impact on a destination's image, as dissatisfied visitors spread negative comments about their experience. The same study conducted by Crick (2003) stated that when residents show hostile feelings towards tourists, negative WOM may reduce visits to tourist attractions.

Tourists develop attitudes based on experiences that he has done or from other sources before deciding to visit. Most researchers who conduct tourist destinations to obtain pleasure relate to exploring between attitudes towards a tourist destination or its image and place preferences as a destination for traveling (Goodrich 1978; Matejka 1973; Mayo 1973; Scott, ETL 1978). Fishbein and Ajzen (1975) emphasize 
that attitude measurement should be based on attitudes toward travel to a particular tourist destination, not on attitudes toward the destination. Oliver (1997) describes attitude as the development of a reasonably stable liking or disliking of a product based on previous experience. In this sense, Oliver (1997) defines behavioral intentions as activities that involve certain behaviors. This attitude is related to the customer's intention to service products or services conveyed by word of mouth. Fishbein and Ajzen (1975) define intention as to future behavior, and there is a tendency to plan so. Based on an evaluation that is carried out appropriately and adequately, an intention is a predictive tool when studying customer behavior in the future.

From the description above, the study's primary purpose is to examine and analyze the effect of electronic word of mouth (eWOM) and Celebrity endorsers on attitudes and intentions to make tourist visits in West Java, Indonesia.

The paper is structured as follows. Section 1 provides an overview of The Influence of Word-Of- Mouth Online and Celebrity Endorser on Attitudes and Intentions of Tourists to Visit Indonesia during the Covid-19 Pandemic. Section 2 reviews the existing literature and provides the background for Word-OfMouth Online and Celebrity Endorser on Attitudes and Intentions. Section 3 develops the hypotheses regarding The Influence of Word-Of-Mouth Online and Celebrity Endorser on Attitudes and Intentions of Tourists to Visit Indonesia during the Covid-19 Pandemic. Section 4 concludes with a discussion of the implications for theory and practice.

\section{Literature Review}

\section{Electronic Word of Mouth (E-WOM)}

WOM communication becomes interesting in promoting a product or service because consumer behavior towards traditional advertising and other marketing communications is less responsive. In the condition of the COVID-19 pandemic, e-WOM is a solution in conveying something without direct interaction with consumers. E-WOM is a development of the concept of WOM (Word of mouth). According to Saleem, Anum, Ellahi, Abida (2017), Word of mouth (WOM) is oral communication in which information is shared in a social environment. It is an informal communication in which consumers discuss brands, products, and services.

E-WOM is defined as informal communication between people to non-commercial communicators and relates to information on brands, products, organizations, and services through internet intermediaries (Tariq et al., 2017). Word of mouth is the primary driver in shaping consumer attitudes and directing behavioral intentions (Chiou and Cheng, 2003; Chevalier and Mayzlin, 2006; Xia and Bechwati, 2008; Jalilvand et al., 2012). Research postulates that WOM communication is more influential than other sources of communication such as advertising and critique recommendations (Smith et al., 2005; Trusov et al., 2009).

Jalilvand and Samiei (2012) define e-WOM as positive or negative statements made by potential, actual, or customer customers about a product or company available to many people and institutions via the Internet. While many customers seek comments about online products or services during the prepurchase stage, many customers also share positive and negative comments about their experiences using online products and services in the post-purchase stage (Bataineh, 2015). According to Kentzo (2020), electronic Word of mouth provides an increase in potential consumer confidence in purchase intentions because of several online reviews, both positive and negative, found on online platforms. This finding is also in line with Sihite's research (2019), which states positive and negative reviews on a product or service. Social media such as Facebook, Instagram, and Twitter can be used as recommendations by consumers in delivering a message. According to Sulthana (2019), electronic 
Word of mouth carried out by family and friends on social media such as Twitter and Facebook is an unpaid promotion. They become a promotional medium for a product and service for free and easily accessible to all consumers.

According to Taungke (2020), electronic Word of mouth is a positive and negative statement about a product or service that consumers have felt through internet media. The statement becomes a strong reason for potential consumers to be interested in or not using the product or visiting a tourist area. If a review or testimonial about a product is obtained from a reliable source, it can influence potential consumers to do the same.

If customers perceive product and service reviews/comments as credible sources, they may use them to make purchasing decisions or visit. Conversely, if it is considered less credible, customers may ignore it (Bataineh, 2015). Research conducted by Tariq et al. (2017) states that e-WOM has a positive and significant effect on purchase intention. This finding is reinforced by Jalilvand \& Samiei's (2012) findings and Semuel \& Lianto's (2014), who expressed a similar opinion.

Research conducted by Dennis et al. (2009), a positive attitude towards e-retailers will affect the intention to buy products or services from e-retailers. This study agrees with Vermeulen and Seegers (2009), which states that online intentions increase to review consumer opinions on services or products and increase awareness of tourist attitudes to visit tourist attractions. Castaneda et al. (2009) examined how tourists' attitudes toward websites and the Internet, in general, can explain attitudes about brands and consumer behavior.

Based on this description, it can be concluded that electronic Word of mouth is a process of sharing opinions and information about products specifically among customers, either in the form of positive or negative statements expressed through various social media (Internet). The following are some of the EWOM indicators proposed by Jalilvand \& Samiei (2012): read reviews, consult, gather information, trust consumer reviews.

Based on this description, the hypotheses in this study are:

Hypothesis H1: e-WOM has a significant effect on tourist attitudes

Hypothesis H2: e-WOM has a significant effect on intention to visit tourist attractions. Celebrity

\section{Endorser}

According to Yan (2018), a celebrity is a movie star, singer, model, athlete, politician, and businessman. Many businesses use celebrity services as an advertising strategy, where celebrities use their social status accounts to promote goods or services based on their popularity and personality. Celebrity endorsement is one form of advertising strategy by utilizing famous people by using their ideas and social status to promote goods or services.

Shafira and Ferdinand (2017) state that a celebrity endorser is a public figure or person known to the public who uses the company to influence consumers to use or demonstrate a product. The characters used in this category are usually YouTubers, soap opera stars, movie stars, famous athletes, politicians, business people, politicians, and the military (Kalangi et al., (2019), Putra and Sulistyawati (2015).

Research conducted by Khan (2018) found that celebrity endorsement positively affects Purchase Intention or the inclination of visits to tourist areas. This finding is supported by the attractiveness, trustworthiness, expertise, and suitability of celebrities. In line with the research of Frimpong and Donkor (2019), celebrity endorsements positively influence purchase intention, which is supported by the attractiveness, trust, and intimacy of celebrities.

When celebrities who are widely known to the public get a role as an endorser, consumers are more likely to buy the product or service they introduce (Farhat \& Khan, 2011). The selection of the right 
celebrity endorser can impact the increase or decrease in sales of a product (Putra \& Sulistyawati, 2015). This opinion is reinforced by the findings of Wibisono and Martini (2016), which state that celebrity endorsers have a positive effect on purchase intention. At the same time, Balabanis (2016) states that celebrity endorsers harm purchase intention.

Some of the literature related to sponsorship, advertising, and celebrity endorsements affects consumer behavior: purchase intention and loyalty (Lafferty \& Goldsmith, 1999) and sponsorship of sports companies (Marshall \& Cook, 1992). The other literature discusses the effect on attitudes and behavior according to endorsers who have experience (Feick \& Higie, 1992) and the perceived compatibility of the endorser with the product or service (Till \& Busler, 1998).

Based on some of these descriptions, it can be concluded that Celebrity Endorser uses celebrities or specific figures who influence advertising a product or service and is intended to support a product. So that it is more easily known and can be conveyed through word of mouth promotion by utilizing social media. According to Kalangi et al. (2019), there are several indicators of celebrity endorsers: 1. Credibility refers to the tendency to trust or trust the endorser. If an information source, such as an endorser, is considered credible. 2. Expertise refers to the knowledge, experience, or skills possessed by the endorser. 3. Trustworthiness refers to perceived honesty, integrity. An endorser is a person whom the audience can trust.

Based on this description, the hypotheses in this study are:

H3: celebrity endorser has a significant effect on tourist attitudes

H4: celebrity endorser has a significant effect on intention to visit tourist attractions

Attitude and Intention

An individual's attitude is demonstrated in the strength and ability to predict certain behaviors. Hede (2005) identified that an individual's attitude towards the city increased significantly because the experience of others in the city (Athens) increased through information through media broadcasts of an activity. Attitudes describe specific individual behavior has been defined as a level or stance that can represent a person's feelings according to or against (Ajzen, 1991). Individuals with a better attitude towards a behavior will have a better and stronger intention to perform the individual behavior (Ajzen, 1991). Behavior is the intention to travel to tourist destinations, and attitude is the attitude of tourists towards the tourist destinations to be addressed.

Tourist behavior can be explained by the intention of tourists to choose a city as their tourist destination. Several researchers (Baloglu \& McCleary, 1999; Choi, Tkachenko, \& Sil, 2011; Hennessey et al., 2010) mention that factors such as the presence of travel stimuli (advertising) and external variables (destination image) play an important role in creating awareness to do activities. Destination, thus influencing the intention of tourists to visit a destination. For example, knowledge about a good image of a destination (e.g., nature tourism) owned by tourists can influence their intention to visit nature tourism (Zhang et al., 2014). Components in advertising or other media promote their interest in visiting a destination created by the tourism industry and other public and private sector destinations (Middleton, 1988).

Tourist attitudes are positively influenced by the image of the destination (Woomi and Soocheong, 2008). There is a positive relationship between attitudes and intentions to choose halal products (Abd Rahman et al., 2015). Ferreira et al. (2012) revealed that entrepreneurial intentions have a significantn and positive effect on entrepreneurial attitudes. Even online, Castaneda et al. (2009) revealed the important role of attitudes towards the internet and websites in explaining brands and consumer electronic behavior. Therefore, the researcher considers Zeithaml's (1988) model as an appropriate framework to study the intention of tourists to visit West Java Province, Indonesia. 
Based on the opinion of the researchers mentioned above, the hypothesis being tested is

H5: The attitude of tourists has a significant effect on the intention to visit tourist attractions Figure 1

below illustrates the hypothesized relationships between the variables.

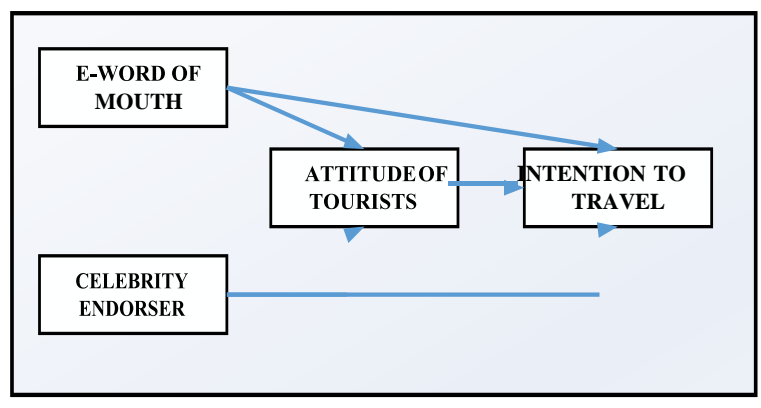

Figure 1. Illustration of the hypothesized model.

\section{Methodology}

This research is explanatory research using a model of the relationship between variables resulting from the development of previous studies and existing theories. Explanatory research, also called explanatory research, examines each variable in-depth to obtain results regarding whether there is a relationship between the symptoms obtained from each variable. The readiness categories model are variables that will be studied in depth so that it is expected to produce a relationship with the overall readiness of the participants.

The study was conducted in West Java, which is a popular tourist destination in Indonesia. Tourist attractions in West Java include Pangandaran beach tourism, Mount Takuban Perahu nature tourism, Bandung city shopping tour, and others. The research target population is local and international tourists - data collection using convenience method. Questionnaires were distributed to respondents via email and social media between March and April 2021, with the number of questionnaires after being sorted amounted to 180 respondents.

\section{Measurement Instrument}

The primary purpose of this study was to determine the effect of e-WOM and celebrity endorsers on tourist attitudes towards destinations and intentions to travel. The first part of the research identifies the socio-demographic characteristics of the sample, which is carried out using items such as gender, age, the purpose of travel, previous visits to Indonesia, and sources of information obtained. The second part involves e-WOM, celebrity endorsers, tourist attitudes towards tourist attractions in West Java, Indonesia, and tourists' intentions to travel. The measurement of the four e-WOM items refers to Jalilvand \& Samiei's (2012) opinion, including reading reviews, consult, gather information, and trust consumer reviews. A modified measurement scale, as suggested by Gamble et al. (2009) were developed, covering items such as very bad (1) to very pleasant (5). The measurement of three celebrity endorser items, referring to the opinion of Kalangi et al. (2019), includes credibility, expertise, (trustworthiness). Then, we measure travel intentions and attitudes by modifying and using the threeitem scale developed by Jalilvand and Samiei (2012). Attitude toward a destination (ATD) is measured through 3 questions as follows: As a tourism destination, Very worthless/Very valuable, Very unpleasant/Very pleasant. Travel intention is measured through three questions:

I will visit tourist attractions, 
I will visit these tourist attractions instead of visiting other tourist destinations, I will plan to visit them in the future in the tourist attractions areas, I think.

The answers to the questionnaire used a Likert scale from strongly disagree (1) to agree (5) strongly.

\section{Analysis Data}

Furthermore, the data and facts from the collected questionnaire will be tested using the Structural Equation Model (SEM) data analysis technique, through the AMOS Version 24 program. The stages of SEM analysis itself must go through at least five stages (Latan., 2013): 1. model specification; 2. model identification; 3. model estimation; 4. model evaluation; 5. Modification or respecification of the model.

Model identification is made by calculating the degree of freedom (df) or degrees of freedom (Latan., 2013). The normality test of the data was carried out by calculating the overall distribution of the data (multivariate). The test is done by calculating the critical ratio (c.r) multivariate (Latan., 2013).

The measurement model shows how the manifest variable (indicator) represents the latent variable to be measured by testing the latent variable's validity and reliability through confirmatory factor analysis. This study will test the construct validity by looking at the convergent validity. Convergent validity will be obtained in SEM processing on AMOS by looking at the factor loading value called the lambda parameter $(\lambda)$. (Ferdinand, (2000).

A validity test relates to whether variable measures what it is supposed to measure. According to Igbaria et., al. (1994), a variable is said to have good validity on the construct or latent variable if the standardized loading factors are 0.50 .

Reliability and validity were carried out before the use of structural modeling. Since the study is quantitative, Cronbach $(\alpha)$ was used to ensure reliability.

\section{Structural Model}

Testing the structural model aims to determine the percentage of the variance of each endogenous variable in the model explained by exogenous variables by looking at R-squares, which is nothing but the value of the squared multiple correlations. Furthermore, R-squares value, evaluation of the structural model can also be done by looking at the significance of the probability value as the basis for accepting or rejecting the null hypothesis. The significance value used is $5 \%$ or $\mathrm{P}<0.05$ and the c.r value $>1.96$ (Latan, 2013:208).

\section{Result}

\section{Demograhics Survey}

The general description of the respondent's profile that the researcher did includes sex, age, number of visits, the purpose of visit, during a tour with, tourist visit information, time of visit (days). The survey results showed that the female sex was $56 \%$ and the male was $44 \%$. Based on the highest age, the age range of 26 to 50 years is $28 \%$, this shows that their age is still productive. Based on the highest number of visits, three visits by $50 \%$, this shows that tourists feel they enjoy the beauty and security and maintain health protocols so that tourists often make repeated visits more than once. Based on the purpose of visit, most tourists do vacations $66 \%$ and business by $11 \%$. This finding shows that tourists have felt bored during the COVID-19 pandemic, so they are looking for entertainment at tourist sites to get rid of boredom while staying at home. Based on during a tour with, $78 \%$ of tourists visit with their families. This finding shows that holidays invite families to visit tourist attractions while maintaining health protocols. Based on tourist visit information, tourists get much information from word of mouth by $39 \%$ and Endorse Celebrity by $28 \%$. This finding shows that word of mouth and endorsement Celebrity information is quite effective in conveying information related to tourist visits. Based on the time of visit (days), $94 \%$ of tourist visits are less than one day, and this is because it is still during the 
Journal of Management and Leadership

Vol.4 No.2, November 2021

covid-19 pandemic, so that tourists do not visit tourist attractions for too long.

A more complete profile of respondents is shown in table 1.

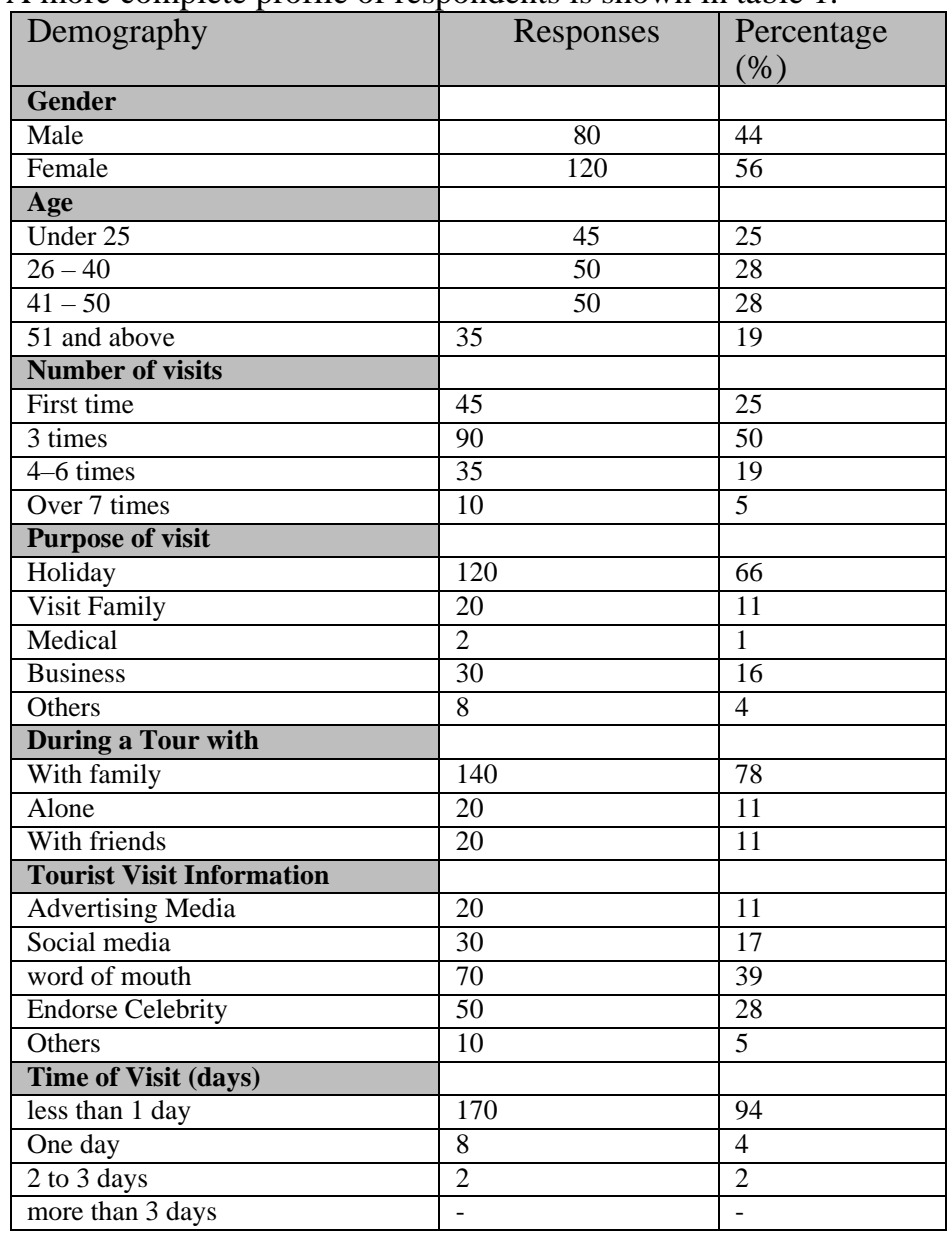

Table 1. Demograhics Survey

Structural Equation Model.

The structural equation model was developed to test the hypotheses proposed in the study. shows an analysis that presents the path coefficients from the independent construct to the corresponding dependent construct as stated in the research hypothesis. 


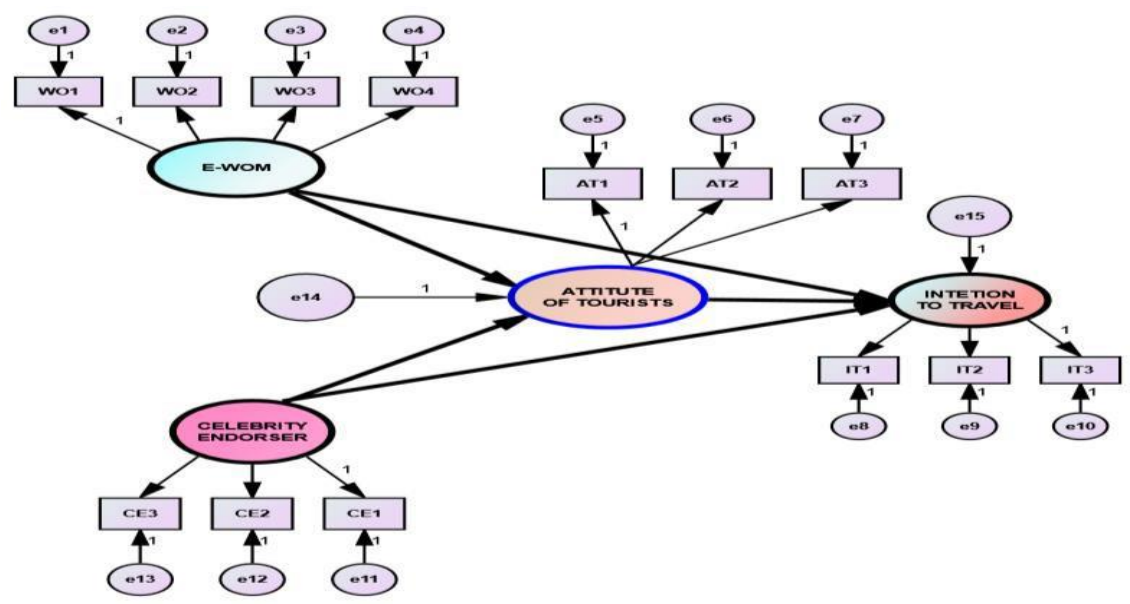

Figure 2. The path coefficient

Reliability and Validity Test Validity Test

Validity testing can be seen from the loading factor value. Based on the AMOS output, this value can be seen in the path diagram. An indicator is said to be valid if the loading factor is greater than 0.5. Based on the AMOS 24 output on the Standardized Regression Weights above, it can be seen that the loading factor value for each indicator has a standard loading factor value $>0.5$ and is declared valid. More complete is shown in the following table:

Table 2. Standardized Regression Weights: (Group number 1 - Default model)

\begin{tabular}{|c|c|c|}
\hline & & Estimate \\
\hline WO1 & $<---$ EWOM & .531 \\
\hline WO2 & $<---$ EWOM & .521 \\
\hline WO3 & $<---$ EWOM & .516 \\
\hline WO4 & $<---$ EWOM & .591 \\
\hline IT3 & <--- INTETION_TRAVEL & .518 \\
\hline IT2 & <--- INTETION_TRAVEL & .574 \\
\hline IT1 & <--- INTETION_TRAVEL & .521 \\
\hline CE1 & <--- CELEBRITY_ENDORSER & .516 \\
\hline CE2 & <--- CELEBRITY_ENDORSER & .542 \\
\hline CE3 & <--- CELEBRITY_ENDORSER & .539 \\
\hline AT1 & <--- ATTITUTE_TOURISTS & 903 \\
\hline AT3 & <--- ATTITUTE_TOURISTS & .656 \\
\hline AT2 & <--- ATTITUTE_TOURISTS & .506 \\
\hline
\end{tabular}

\section{Reliability Test}

Testing the reliability of the instrument obtained results, the variables of company performance, market orientation, and the use of e-commerce were declared reliable. In SPSS, facilities are provided to measure reliability with the Cronbach Alpha $(\alpha)$ statistical test, a construct or variable is said to be reliable if it gives a Cronbach Alpha value > 0.60 (Ghozali, 2016) 
Journal of Management and Leadership

Vol.4 No.2, November 2021

Table 3: Instrument Reliability Test Results

\begin{tabular}{|c|c|c|c|}
\hline Variabel & Cronbach Alpha & Cut Off & Conclution \\
\hline EWOM & 0,793 & 0,60 & Reliabel \\
\hline CELEBRITY_ENDORSER & 0,812 & 0,60 & Reliabel \\
\hline INTETION_TRAVEL & 0,799 & 0,60 & Reliabel \\
\hline ATTITUDE_TOURISTS & 0,725 & 0,60 & Reliabel \\
\hline
\end{tabular}

From all the assumption tests carried out, it can be concluded that all values have met the standards that have been set and then a hypothesis test can be carried out.

\section{Structural Model Analysis}

Structural model analysis is a full model structural equation modeling (SEM) analysis, after analyzing the level of unidimensionality of the indicators forming the exogenous and endogenous latent variables tested by confirmatory factor analysis. Analysis of the results of data processing at the full stage of the SEM model was carried out by conducting conformity tests and statistical tests. The results of data processing for the full SEM model analysis are shown in Figure 3.

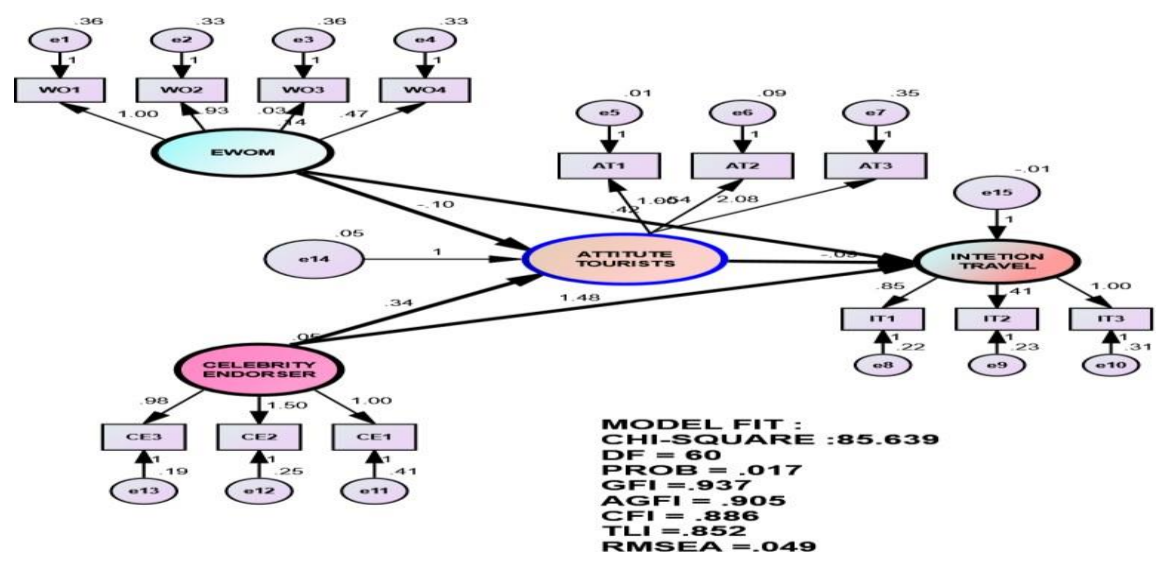

Figure 3. Structural Model

\section{Evaluation of the Goodness Of Fit Criteria Index}

The calculation results of the SEM model as shown in Figure 3 produce a goodness of fit index as shown in Table 4.

Table 4. Indeks Goodness Of Fit

\section{Measurement Model}

$\begin{array}{llll}\text { Criteria } & \text { Result } & \text { Critical Value } & \text { Conclusion } \\ \text { Chi-square } & 85,639 & \text { small } & \text { Good } \\ \text { p-value } & 0,017 & \geq 0,05 & \text { Good } \\ \text { RMSEA } & 0,049 & \leq 0,08 & \text { Good } \\ \text { GFI } & 0,937 & \geq 0,90 & \text { Good } \\ \text { AGFI } & 0,905 & \geq 0,90 & \text { Good } \\ \text { CMIN/DF } & 1,063 & \leq 2,00 & \text { Good } \\ \text { TLI } & 0,852 & \geq 0,95 & \text { Marginal } \\ \text { CFI } & 0,886 & \geq 0,95 & \text { Marginal }\end{array}$

In the analysis of this measurement model, it is explained about the relationship between indicators and variables through mathematical equations and the final results that have been obtained from testing using AMOS version 
24. The following is the mathematical equation.

a. Variable Attitude Tourist

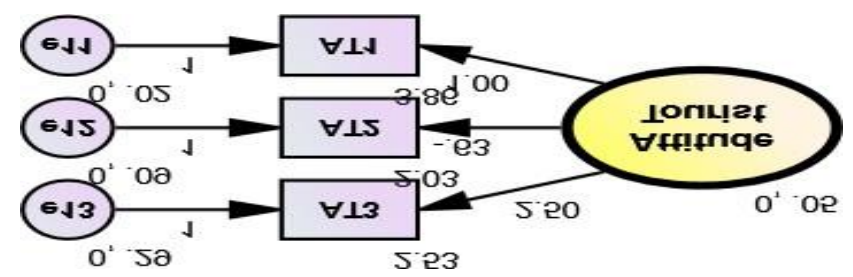

Figure 4 Equation of Tourist Attitude Model AT1 $=2,50 \xi 1+0,29$

$\mathrm{AT} 2=0,63 \xi 2+0,09$ AT3 $=1,00 \xi 3+0,02$

So based on the above equation it can be seen that: The AT1 indicator gives an effect of 2.50

The AT2 indicator has an effect of -0.63 The AT3 indicator has an effect of 1.00

b. Variable Intention Travel

Figure 5 Equation of

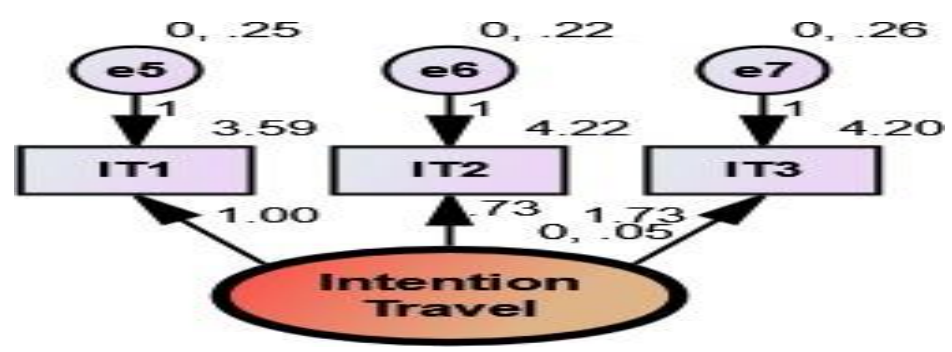

Travel Intention Model

IT $1=1,00 \xi 1+3,59$ IT2 $=0,73 \xi 2+4,22$ IT $3=1,73 \xi 3+4,20$

So based on the above equation it can be seen that:

The IT1 indicator has an effect of 1.00 The IT2 indicator has an effect of 0.73 The IT3 indicator has an effect of 1.73

c. Variable Celebrty Endorse

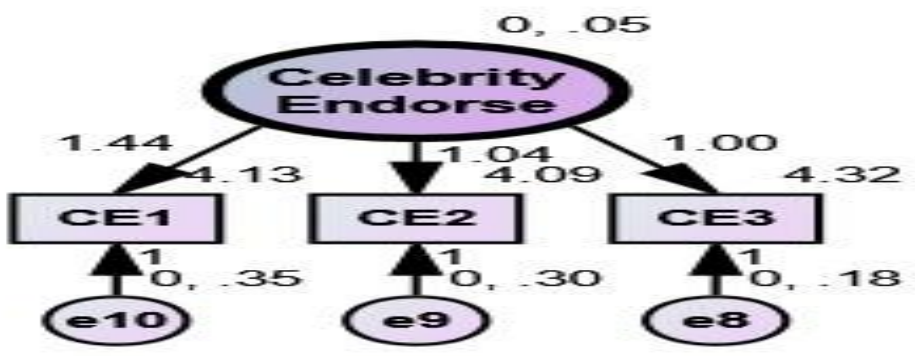

Figure 6 Equation of Celebrty Endorse Model 


$$
\begin{aligned}
& \mathrm{CE} 1=1,44 \xi 1+0,35 \\
& \mathrm{CE} 2=1,04 \xi 2+0,30 \mathrm{CE} 3=1,00 \xi 3+0,18
\end{aligned}
$$

So based on the above equation it can be seen that:

The CE1 indicator has an effect of 1.44 The CE2 indicator has an effect of 1.04 The CE3 indicator has an effect of 1.00

d. Variable Electronic Worth of Mouth (e-wom)

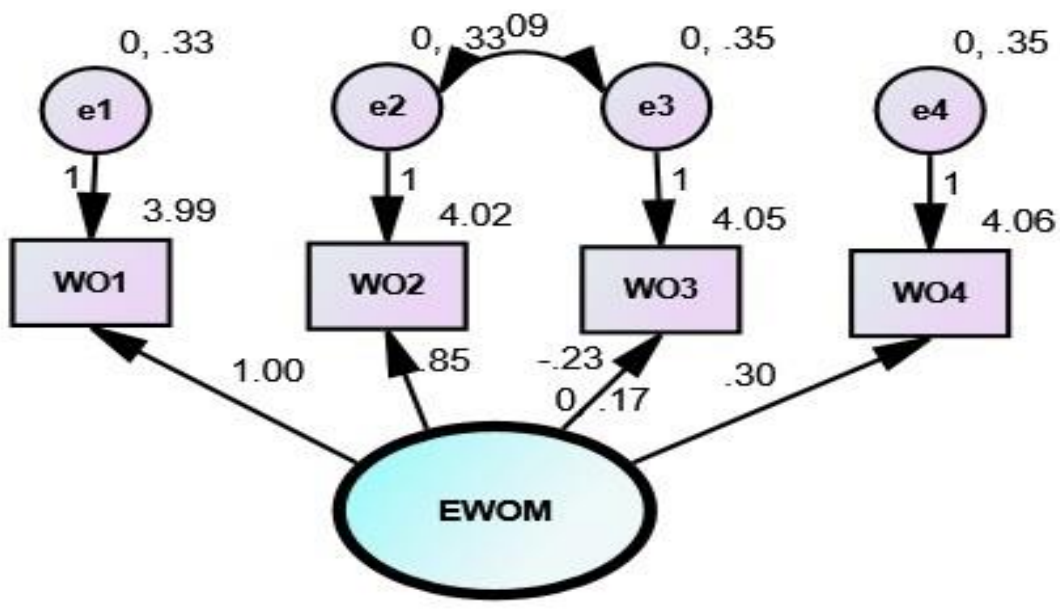

Figure 7 Equation of the Electronic Worth of Mouth Model

$$
\begin{aligned}
\mathrm{WO} 1 & =1,00 \xi 1+3,99 \\
\mathrm{WO} 2 & =0,85 \xi 2+4,02 \mathrm{WO} 3=-0,23 \xi 3+4,05 \mathrm{WO} 4=0,30 \xi 4+4,06
\end{aligned}
$$

So based on the above equation it can be seen that:

The WO1 indicator has an effect of 1.00 The WO2 indicator has an effect of 1.85 The WO3 indicator has an effect of -2.23 The WO4 indicator has an effect of 0.30

\section{Data Normality Test}

Estimation with maximum likelihood requires the observed variables to meet the assumption of multivariate normality. Evaluation of multivariate normality with AMOS 24 was carried out using the critical ratio (C.R.) criteria of multivariate in kurtosis, if it is in the range of -2.58 to 2.58 , it can be concluded that the data is normally distributed. The normality test of the data can be seen in Table 5 as follows: 
Table 5. Assessment of normality (Group number 1)

\begin{tabular}{|l|rrrrrr|}
\hline Variable & min & Max & skew & c.r. & kurtosis & c.r. \\
\hline CE3 & 2.000 & 5.000 & -.282 & -1.758 & .118 & .415 \\
CE2 & 2.000 & 5.000 & -.055 & -.337 & .562 & 1.712 \\
CE1 & 2.000 & 5.000 & -.123 & -.748 & .584 & 1.779 \\
IT1 & 3.000 & 5.000 & .137 & .836 & -.150 & -.457 \\
IT2 & 2.000 & 5.000 & -.095 & -.582 & .648 & 1.975 \\
IT3 & 3.000 & 5.000 & .240 & 1.460 & -.583 & -1.778 \\
AT3 & 3.000 & 5.000 & .093 & .566 & .072 & .220 \\
AT2 & 2.000 & 5.000 & -.276 & -1.682 & .369 & .912 \\
AT1 & 2.000 & 5.000 & -.148 & -.902 & -.271 & -.827 \\
WO4 & 3.000 & 5.000 & .025 & .153 & -.137 & -.419 \\
WO3 & 2.000 & 5.000 & -.300 & -1.830 & .580 & 1.770 \\
WO2 & 3.000 & 5.000 & -.310 & -1.890 & -.656 & -1.985 \\
WO1 & 2.000 & 5.000 & -.077 & -.471 & -.574 & -1.749 \\
Multivariate & & & & & 51.702 & 19.548 \\
\hline
\end{tabular}

Hypothesis Testing

From the results of hypothesis testing shows the following results:

i. Hypothesis 1: e-WOM has a significant effect on tourist attitudes

The results show that e-WOM has no significant effect on tourist attitudes, where the probability value is

0.223. This result contradicts the proposed hypothesis.

ii. Hypothesis 2: e-WOM has a significant effect on intention to visit tourist attractions.

The results show that e-WOM has a significant effect on the intention to visit tourist attractions, where the probability value is 0.019 . These results support the proposed hypothesis.

iii. Hypothesis 3: celebrity endorser has a significant effect on tourist attitudes

The results show that celebrity endorsers have a significant effect on tourist attitudes, where the probability value is 0.035 . These results support the proposed hypothesis.

iv. Hypothesis 4: celebrity endorser has a significant effect on intention to visit tourist attractions. The results show that celebrity endorsers have a significant effect on intentions to visit tourist attractions, where the probability value is 0.000 . These results support the proposed hypothesis.

v. Hypothesis 5: Tourist attitudes have a significant effect on intentions to visit tourist attractions. The results show that the attitude of tourists has no significant effect on the intention to visit tourist attractions, where the probability value is 0.699 . This result contradicts the proposed hypothesis. 
Completely the results of hypothesis testing can be explained in table 6 below:

Table 6. Regression Weights: (Group number 1 - Default model)

\begin{tabular}{|c|c|c|c|c|c|}
\hline & Estimate & S.E. & C.R. & $\mathrm{P}$ & Label \\
\hline ist $<---\mathrm{Cel}$ & .335 & .159 & 2.109 & .035 & ar_10 \\
\hline Attitude_Tourist <--- Ewom & -.098 & .081 & -1.219 & .223 & \\
\hline Intention_Travel <--- Attitude & -.066 & .172 & -.386 & .699 & \\
\hline Intention_Travel <--- Ewom & .353 & .151 & 2.339 & .019 & $\operatorname{ar}$ \\
\hline Intention_Travel <--- Celebrity_Endorse & 1.232 & .367 & 3.355 & $* * *$ & par_1 \\
\hline
\end{tabular}

Analisis Direct Effect

The results of the direct influence measurement show that the variable that has the greatest direct influence on the Attitude_Tourist variable is the Celebrity_Endorse variable, which is 0.335 and has a significant effect. The smallest direct effect is the variable ewom which has an effect of -.098 and has no significant effect. The biggest direct effect on the Intention_Travel variable is the Celebrity_Endorse variable, which is 1.232 and has a significant effect. The smallest direct effect is the Attitude Tourist variable of -0.066 and has no significant effect.

The direct effect of this research model is presented in Table 7

Table 7. Standardized Direct Effects - Estimates

\begin{tabular}{|c|c|c|c|c|}
\hline & Ewom & $\begin{array}{l}\text { Celebrity } \\
\text { Endorse }\end{array}$ & $\begin{array}{r}\text { Attitude } \\
\text { Tourist }\end{array}$ & $\begin{array}{r}\text { tention } \\
\text { Travel } \\
\end{array}$ \\
\hline Att & $\begin{array}{l}.098 \\
\end{array}$ & .335 & .000 & .000 \\
\hline Intention_Travel & .353 & 1.232 & -.066 & .000 \\
\hline
\end{tabular}

\section{Indirect Effect}

The results of the indirect influence measurement show that the variable that has the largest indirect effect on the Attitude_Tourist variable is the Celebrity_Endorse variable, which is 0.290 and has a significant effect. The smallest indirect effect is the variable ewom which has an effect of -.150 and has no significant effect. The biggest indirect effect on the Intention_Travel variable is the Celebrity_Endorse variable, which is 0.900 and has a significant effect. The smallest indirect effect is the Attitude Tourist variable of -0.056 and has no significant effect.

Table 8. Standardized indirect Effects - Estimates

\begin{tabular}{|c|c|c|c|}
\hline & $\begin{array}{r}\text { Celebrity } \\
\text { Ewomdorse }\end{array}$ & $\begin{array}{r}\text { Attitude } \\
\text { Tourist }\end{array}$ & $\begin{array}{r}\text { itention } \\
\text { Travel }\end{array}$ \\
\hline Attitude_Tourist & -.150 & .000 & .000 \\
\hline Intention_Travel & .456 & -.056 & .000 \\
\hline
\end{tabular}




\section{Total Effect}

From the table, it is shown that the first highest total influence is celebrity endorser on travel intention of 2,132 . Both e-woms on travel intention are 0.809 . This shows the role of celebrity endorsers and ewom in contributing to influencing the attitudes and intentions of tourists to make tourist visits.

Table 9. Total Effects (Group number 1 - Default model)

\begin{tabular}{|l|rrrr|}
\hline & EWOM $\begin{array}{c}\text { CELEBRITY } \\
\text { ENDORSER }\end{array}$ & $\begin{array}{r}\text { ATTITUTE } \\
\text { TOURISTS }\end{array}$ & $\begin{array}{r}\text { JTETION_ } \\
\text { TRAVEL }\end{array}$ \\
\hline ATTITUTE_TOURISTS & -.248 & .625 & .000 & .000 \\
INTETION_TRAVEL & .809 & 2.132 & -.122 & .000 \\
\hline
\end{tabular}

\section{DISCUSSION AND IMPLICATIONS}

During the COVID-19 pandemic, the tourism industry was mainly affected because the government imposed regulations that limited public access so that most tourist visits were deserted. The tourismrelated industries such as hotels, , tourist attraction managers, , travel agents, airlines, restaurants, souvenir centers, and tour guides have had an impact, which has decreased business income. It takes the cooperation of all related tourism components and anticipates various dynamics focusing on domestic and international tourists. Trunfio et al. (2006) stated the importance of analyzing the regional approach as a cluster that identifies the collective strategy of the role played by tourism operators in developing new tourism destinations and places. Baum and Hai (2020) state that the hospitality and tourism industry is receiving an unprecedented large-scale impact. Therefore, tourism industry players are required to utilize other marketing strategies to market their products creatively.

The results of the study show that eWOM does not have a significant effect on tourist attitudes. This is possible due to the ongoing covid-19 pandemic, where there is a government policy that closes tourist attractions to prevent the spread of COVID-19. The precautionary attitude of tourists due to fear of contracting the Covid-19 disease makes their attitude passive and delays traveling to tourist attractions. On the other hand, e-WOM has a significant effect on intentions to visit tourist attractions. This shows that if the e-WOM is delivered following the conditions of the tourist site, for example, it has carried out suitable health protocols. There is a possibility that the prospective tourist will immediately have the intention of making a tourist visit. E-wom that is carried out continuously and individual boredom due to being at home too long makes them intend to take a vacation. Specifically, there are three dimensions included in the credibility of eWOM: (a) trust, (b) expertise (c) sociability. Tourists assess that when these three criteria have been achieved, it will positively affect visits to tourist attractions. Information that will be conveyed through e-wom must have a standard and not contradict with other parties. The information submitted must be honest, measurable, correct, and conveyed by people who have the credibility to give a better image of tourist attractions. With conditions during the COVID-19 pandemic, it is necessary to involve all sectors, such as tourism, health, and local government.

The existence of e-wom cannot be separated from the content of the information to be conveyed. From an informational perspective, it is necessary to establish established procedures and enable hospitality and tourism marketers to obtain online feedback. Information collected about properties and tourist destinations can then be used to solve problems such as increasing visitor satisfaction through product improvements. Examples of product improvement are discovering what visitors are saying - good and bad - about their experience, analyze competitive strategy, and monitor the reputation/image of the company. Equally important is the need to manage eWOM to generate revenue (Kirkpatrick and Roth 
2005). These efforts can spread good WOM about the property and destination - helping potential visitors find information by providing compelling images and opinions. Encouraging or stimulating good eWOM should result in increased business activity.

Based on the research results, celebrity endorsers significantly affect tourists' intentions and attitudes in making visits. The choice of celebrity endorsers is essential to develop e-WOM to inform positive things about tourist attractions. In the US and Europe, advertising agencies and clients prefer celebrity endorsers with traits such as public trust, familiarity, and credibility (Erdogan, Baker \& Tagg, 2001). In tourist areas in West Java, Indonesia often uses YouTubers, artists, and bloggers in conveying information on tourist attractions. They have an attractive physical appearance and are known by the public. Studies show that the physical attractiveness of a celebrity endorser has a positive impact on people's attitudes toward advertising and brands (Kamin 1990; Petroshius and Crocker 1989).

The existence of e-wom cannot be separated from the content of the information to be conveyed. From an informational perspective, it is necessary to establish established procedures and enable hospitality and tourism marketers to obtain online feedback. Information collected about properties and tourist destinations can then be used to solve problems such as increasing visitor satisfaction through product improvements; solve visitor problems; discover what visitors are saying - good and bad - about their experience; analyze competitive strategy, and monitor the reputation/image of the company. Equally important is the need to manage eWOM to generate revenue (Kirkpatrick and Roth 2005). These efforts can spread good WOM about the property and destination - helping potential visitors find information by providing compelling images and opinions. Encouraging or stimulating good eWOM should result in increased business activity.

Based on the research results, celebrity endorsers significantly affect tourists' intentions and attitudes in making visits. The choice of celebrity endorsers is critical to developing e-WOM to inform positive things about tourist attractions. In the US and Europe, advertising agencies and clients prefer celebrity endorsers with traits such as public trust, familiarity, and credibility (Erdogan, Baker \& Tagg, 2001). In tourist areas in West Java, Indonesia often uses YouTubers, artists, and bloggers in conveying information on tourist attractions. They have an attractive physical appearance and are known by the public. Studies show that the physical attractiveness of a celebrity endorser has a positive impact on people's attitudes toward advertising and brands (Kamin 1990; Petroshius and Crocker 1989).

Attention to changes and global threats such as terrorism, disease outbreaks need to be anticipated. Therefore proactive and sustainable preventive actions need to be taken (Brooker \& Burgess, 2008). Based on this, it is necessary to define the concept of sustainable tourism as proposed in research conducted by Dixon (2017), which reports the need to pay attention to geopolitical conditions and imitate Canadian tourism. Therefore, this concept needs to be strengthened by defining a unique market position so that tourism is economically sustainable. The application of Virtual Reality Tourism can be an option to increase public interest in traveling during the COVID- 19 pandemic. Virtual Tourism is present as a form of transformation and adaptation against the pandemic by utilizing technology while waiting for the recovery process of the tourism world, which has not been significant. The International Air Transport Association (IATA) estimates that travel will not return to pre-pandemic levels until 2024 ( BBC, 2020). Virtual Tourism can be a temporary answer to keep potential tourists interested in traveling when conditions improve.

The idea of Virtual Tourism was started and developed by various parties, such as the Ministry of Tourism and Creative Economy, the local government, and the community. The content in this Virtual Tour is also very diverse, ranging from natural panoramas, museums, art performances and performances, traditional culture to the atmosphere of urban life in Indonesia, which is available in the form of images and videos. The hope is that virtual tourism can make potential tourists feel like they are in the destination they want. This is tantamount to offering a "try before you buy" experience that can encourage travel.

To realize the Implementation of Virtual Reality Tourism requires the involvement of all components on an ongoing basis through training and mentoring. As stated by Johnston and Tyrrell (2007), Salazar and Cardoso (2019) stated the importance of providing training and development to understand 
sustainable tourism, which anticipates the dynamics of economic conditions, tourist behavior, and the environment., it is necessary to establish comprehensive indicators, such as economic, socio-cultural, psychological, political, organizational factors, tourism commercialization, physical environment, and community psychological factors. The COVID-19 pandemic has become a momentum and can be used to consider implementing Virtual Reality Tourism as a solution.

\section{Conclusion and Recommendation}

Electronic word-of-mouth (eWOM) messages are statements delivered online about products or services and related services posted by potential, actual, and future customers. Luo and Zhong (2015) suggest eWOM as a source of appropriate and accurate information and can be relied upon to shape consumer expectations and influence post-purchase and purchase decisions. Promotions carried out by celebrity endorsers are considered to positively impact individual attitudes and lead to intentions to behave positively. Celebrity endorsers can provide reviews in interesting language from what they see and feel, which will grow the interest and desire of tourists to visit tourist attractions. Kamins (1990) argues that the right and attractive celebrity is a more effective endorser than a product used to increase its attractiveness. Thus celebrity endorsers can provide attraction and provide attitudes and intentions of tourists to visit.

Communication by word of mouth (WOM) and celebrity endorsers is one of the influential communication media between message communicators and message recipients on an object to be conveyed. Both of these media can be considered reliable and relevant sources of information because this communication is more likely to generate and grow the interest and desire of tourists to visit tourist sites and reduce their resistance to products and services.

The COVID-19 pandemic has gained momentum and considered implementing Virtual Reality Tourism as a solution before tourists decide to make a tourist visit. Celebrity endorsers, such as YouTubers, can carry out information dissemination on Virtual Reality Tourism.

\section{Limitations and Future Research}

Although some research results support the hypothesis, there are also some limitations. Considering the increasing condition of the COVID-19 pandemic, it becomes an obstacle for researchers, for example, time issues, accessibility, and sampling, and maintaining health protocols while conducting research. The limitations of the indicators studied are also obstacles, for example, the problem of the different cultural context of each tourist, beliefs, attitudes, behavior, and lifestyle. Another limitation is that the diversity of celebrities is minimal and not comprehensively researched, for example, YouTubers, bloggers, athletes, actors, singers, journalists.

For future research, including a more diverse population from different geographic locations and examining the adverse effects of celebrity e-wom endorsers, which can lead to negative attitudes towards tourist destinations, we can find out what the cause is.

\section{References}

Abd Rahman, A., Asrarhaghighi, E. and Ab Rahman, S. (2015). Consumers and Halal cosmetic products: knowledge, religiosity, at intention. Journal of Islamic Marketing, 6(1), pp.148-163

Agrawal, J., and W. A. Kamakura. (1995). "The Economic Worth of Celebrity Endorsers: An Event Study Analysis.” Journal of Marketing, 59 (3): 56-63

Andrews, D. L., and S. J. Jackson. (2001). Sports Stars: The Cultural Politics of Sporting Celebrity. New York: Routledge

Adjei, M., Noble, S., Noble, C. (2009). The influence of C2C communications in online brand communities on customer purchase behavior. Journal of the Academy of Marketing Science, 
38(5), pp.634-653

Ajzen, I. (1991). The theory of planned behavior.Organ.Behav. Hum. Decis. Process, 50(2), 179-211. http://dx.doi.org/10.1016/0749-5978(91)90020-T

Balabanis, M. S. (2016). Sometimes a Celebrity Holding a Negative Public Image is The Best Product Endorser. European Journal of Marketing, 1-41.

Baloglu, S., \& McCleary, K. W. (1999).A model of destination image formation.Annals of Tourism Research, 26(4), 868e897.

Bataineh, A. Q. (2015). The Impact of Perceived e-WOM on Purchase Intention : The Mediating Role of Corporate Image. International Journal of Marketing Studies, 126- 137

Baum, T., \& Hai, N. T. T. (2020).Hospitality, tourism, human rights and the impact of COVID19.International Journal of Contemporary Hospitality Management, 32(7), 23972407.https://doi.org/10.1108/IJCHM-03-2020-0242.

Brooker, E., \& Burgess, J. (2008).Marketing destination Niagara effectively through the tourism life cycle. International Journal of Contemporary Hospitality Management, 20(3), 278-292. https://doi.org/10.1108/0959611081086609.

Brown, J., Broderick, A., and Lee, N. (2007). Word Of Mouth Communication within Online Communities: Conceptualizing the Online Social Network. Journal of Interactive Marketing, 21(3), pp.2-20

Castaneda, J. A., Rodriguez, M. A., \& Luque, T. (2009).Attitudes' hierarchy of effects in online user behavior. Online Inform. Rev, 33(1), 7-21. http://dx.doi.org/10.1108/14684520910944364

Charo, N., Sharma, P., Shaikh, S., Haseeb, A. and Sufya, M. (2015).Determining the Impact of Ewom on Brand Image and Purchase Intention through Adoption of Online Opinions. International Journal of Humanities and Management Sciences (IJHMS), 3(1), pp.41-46

Choi, J. G., Tkachenko, T., \& Sil, S. (2011).On the destination image of Korea by Russian tourists.Tourism Management, 32(1), 192e194.

Crick, A.P. (2003) Internal marketing of attitudes in Caribbean tourism. International Journal of Contemporary Hospitality Management, 15 (3), 161-166.

Deasy, G. and Griess, P., 1966. Impact of a tourist facility on its hinterland. Annals of the Association of American Geographers, 56(2), pp. 290-306.

Dennis, C., Merrilees, B., Jayawardhena, C., \& Wright, L. (2009), E-consumer behavior. European Journal of Marketing, 43(10), 1121-1139. http://dx.doi.org/10.1108/03090560910976393

Dixon, A. (2017). The path to embed sustainability in Canadian tourism companies. Worldwide Hospitality and Tourism Themes, 9(4), 433-441. https://doi.org/10.1108/WHATT-04-2017-0019

Elkan, W., 1975.The Relation between Tourism and Employment in Kenya and Tanzania. Journal of Development Studies, 11(2), pp. 123-130.

Erdogan, B. Z. (1999). Celebrity endorsement: A literature review. Journal of Marketing Management, 15(4), 291-314.

Erdogan, B. Z., Baker, M. J., \& Tagg, S. (2001). Selecting celebrity endorsers: The practitioner's perspective.Journal of Advertising Research, 41(3), 39-48.

Erkuş-Öztürk, H. (2016). Diversification of hotels in a single-asset tourism city.In Tourism and hospitality management (Advances in culture, tourism and hospitality research, Vol. 12, pp. 173185).Emerald Group Publishing. https:// doi.org/10.1108/S1871-317320160000012013

Farhat, R., \& Khan, B. M. (2011). Importance of Brand Personality to Customer Loyalty : A Conceptual Study. Aligarh: Aligarh Muslim University (AMU).

Ferreira, J., Raposo, M., Gouveia Rodrigues, R., Dinis, A. and do Paço, A. (2012). A model of entrepreneurial intention: An application of the psychological and behavioral approaches. Journal of Small Business and Enterprise Development, 19(3), pp.424-440. 
Febrantara, D. (2020). Bagaimana Penanganan UKM di Berbagai Negara Saat Ada Pandemi Covid19 ? DDTC Fiscal Research.Retrieved from https://drive.google.com/drive/folders/1MY31IOC3gWq-EgzNkuJzqJnB9PV6qA2D

Feick, L., \& Higie, R. A. (1992). The effects of preference heterogeneity and source characteristics on ad processing and judgements about endorsers. Journal of Advertising, 21(2), 9-24.

Ferdinand, Augusty. (2000). Structural Equation Modelling dalam Penelitian.Manajemen. Semarang: Penerbit Universitas Diponegoro.

Fishbein, M., and I. Ajzen 1975 Beliefs, Attitude, Intention and Behavior: An Introduction to Theory and Research. Reading MA: Addison-Wesley.

Formica, S., \& Kothari, T. H. (2008). Strategic destination planning: analyzing the future of tourism. Journal of Travel Research

Forrester, S. (2006). The State Of Retailing Online: The 9th Annual Shop.org Study. Published by Shop.org, June 2006. Rrieved June 21, 2013, from http:// www.clickz.com/3611181

Frimpong, K.O, Donkor, J, \& Frimpong, N.O. (2019). The Impact of Celebrity Endorsement on Consumer Purchase Intention: An Emerging Market Perspective. Journal of Marketing Theory and Practice, 27(1), 103-121.

Godes, D. and Mayzlin, D. (2004).Using online conversation to study word-of-mouth communication. Marketing Science, 23(4), pp.545-560

Goodrich, J. N. 1978 The Relationship Between Preferences for and Perceptions of Vacation Destinations: ADDlication of a Choice Model. Tournal of Travel Research 17:8-13.

Ghozali, I., 2016. Aplikasi Analisis Multivariate dengan Program SPSS”. Badan Penerbitan Universitas Diponegoro Semarang, edisi 2.

Gretzel, U., \& Yoo, K. (2008). Use and impact of online travel reviews. In O'Connor, P., Hopken, W., \& Gretzel, U. (Eds.), Information and communication technologies in tourism (pp. 35-46). New York: Springer-Verlag.

Gunn, C., 1977. Industry pragmatism vs. tourism planning. Leisure Sciences: An Interdisciplinary Journal, 1(1), pp. 85-94.

Hede, A. (2005). Sports-events, tourism and destination marketing strategies: an Australian case study of Athens 2004 and its media telecast. Journal of Sport Tourism, 10(3), 187e200.

Hennessey, S. M., Yun, D., MacDONALD, R., \& MacEACHERN, M. (2010). The effects of advertising awareness and media form on travel intention. Journal of Hospitality Marketing and Management, 19, 217e243.

Hsu, C., and D. McDonald.(2002). "An Examination on Multiple Celebrity Endorsers in Advertising." Journal of Product and Brand Management, 11 (1): 19-29

Jalilvand, M. and Samiei, N. (2012). The effect of electronic word of mouth on brand image and purchase intention.: An empirical study in the automobile industry in Iran, Marketing Intelligence \& Planning, 30(4), pp.460-476.

Jalilvand, M., Samiei, N., Dini, B. and Manzari, P. (2012).Examining the structural relationships of electronic word of mouth, destination image, tourist attitude toward destination and travel intention: An integrated approach.Journal of Destination Marketing \& Management, 1(1-2), pp.134-143.

Johnston, R. J., \& Tyrrell, T. J. (2007)."Management exercises and trainer's note in sustainable tourism and dynamics. International Journal of Culture, Tourism and Hospitality Research, 1(4), 328-337. https://doi.org/10.1108/ 17506180710824217

Kalangi, N. J., Tamengkel, L. F., \& Walangitan.(2019). Pengaruh Celebrity Endorser dan Brand Image Terhadap Keputusan Pembelian Shampoo Clear. Jurnal Administrasi Bisnis, 44-54.

Kamins, M. A. (1990). "An Investigation into the 'Match-Up' Hypothesis in Celebrity Advertising: When Beauty May Be Only Skin Deep.” Journal of Advertising, 19 (1): 4-13

Kamins, M. A. (1990). “An Investigation into the 'Match-Up' Hypothesis in Celebrity Advertising: 
When Beauty May Be Only Skin Deep.” Journal of Advertising, 19 (1): 4-13.

Kentzo, Claudia,G.A, Siaputra,H \& Iskandar,V (2020) Analisa Pengaruh eWOM Terhadap Minat Beli Konsumen Setelah Kejadian Food Poisioning di Restoran X Surabaya Dengan Citra Merek Sebagai Mediator.Jurnal Hospitality dan Manajemen Jasa, 8(1), 1- 14

Khan, M.M. (2018). The Effect of Celebrity Endorsement on Consumer Purchase Intention - Evidence from Q Mobile Linq Advertisement. Journal of Marketing Management, 15(4), 1065-1082

Kirkpatrick, D. and Roth, D. (2005) Why there's no escaping the blog. Fortune, January 10, 44-50.

Ladhari, R. and Michaud, M. (2015).eWOM effects on hotel booking intentions, attitudes, trust, and website perceptions. International Journal of Hospitality Management, 46, pp.36-45

LatanHengky .(2013). Model Persamaan Struktural Teori dan Implementasi. Bandung: CV. Alfabeta.

Lafferty, B. A., \& Goldsmith, R. E. (1999).Corporate credibility's role in consumers' attitudes and purchase intentions when a high versus a low credibility endorser is used in the ad. Journal of Business Research, 44(2), 109-116

Lee, K. and Koo, D. (2012). Effects of attribute and valence of eWOM on message adoption: Moderating roles of subjective knowledge and regulatory focus. Computers in Human Behavior, 28(5), pp.1974-1984.

Lee, M., Rodgers, S. and Kim, M. (2009). Effects of Valence and Extremity of eWOM on Attitude toward the Brand and Website.Journal of Current Issues \& Research in Advertising, 31(2), pp.111.

Li, F.A. 2008. Study on the factors about tourism risk sense based on logit model. A case study of earthquake in Sichuan on May 12. Tourism Forum, 6, 31-36.'

Lin, C., Wu, Y. and Chen, J. (2013). Electronic word-of-mouth: the moderating roles of product involvement and brand image. In: International conference on technology innovation and Industrial Management. Phuket, Thailand, pp.29-47.

Luo, Q \& Zhong, D. 2015. Using social network analysis to explain communication characteristics of travel-related electronic word-of-mouth on social networking sites, Tourism Management,.46(1),274- 282.

Igbaria, M., N. Zinatelli, P. Cragg, dan A. L. M. Cavaye, (1997), "Personal Computing Acceptance Factors in Small Firms: A Structural Equation Model", MIS Quartertly, 21/3 : 279 - 305.

Matejka, J. K. 1973 Critical Factors in Vacation Area Selection. Arkansas Business and Economic Review 6:17-19.

Marshall, D. W., \& Cook, G. (1992). The corporate (sports) sponsor. International Journal of Advertising, 11(4), 307-324.

Mayo, E. J. 1973 Regional Images and Regional Travel Destination. In Proceedings of The Fourth Annual Conference of TTRA. pp. 211-217. Salt Lake City UT Travel and Tourism Research Association.

Middleton, V. T. C. (1988). Marketing in travel and tourism. Oxford: Heinemann.

Mings, R., 1969. Tourism's Potential for Contributing to Economic Development in the Caribbean. Journal of Geography, 68(3), pp. 173-177.

Morgan, N.J., Pritchard, A. and Piggott, R. (2003) Destination branding and the role of the stakeholders: The case of New Zealand. Journal of Vacation Marketing, 9 (3), 285-299.

OECD. (2020). SME Policy Responses: Tackling Coronavirus (Covid-19) Contributing to A Global Effort. Retrieved from https://oecd.dam-broadcast.com/pm_7379_119_119680di6h3qgi4x.pdf

Oliver, R. L. (1997). Customer Satisfaction.A Behavioral Perspective on the Consumer. New York: McGraw-Hill.

Park, S. Y., \& Yim, M. Y. C. (2020). Do celebrity endorsements benefit familiar luxury brands? A perspective from social adaptation theory. Journal of Current Issues and Research in Advertising, 41(1), 20-35. 
Petroshius, S. M., and K. E. Crocker.(1989). "An Empirical Analysis of Spokesperson Characteristics on Advertisement and Product Evaluations." Journal of the Academy of Marketing Science, 17 (3): $217-25$.

Putra, I. K., \& Sulistyawati.(2015). Peran Brand Image Dalam Memediasi Pengaruh Celebrity Endorser Terhadap Niat Beli. E-Jurnal Manajemen Unud, 1722-1734.

Sadler, P. and Archer, B., 1975. The economic impact of tourism in developing countries. Annals of Tourism Research, 3(1), pp. 15-32.

Salazar, A., \& Cardoso, C. (2019). Tourism planning: Impacts as benchmarks for sustainable development plans. Worldwide Hospitality and Tourism Themes, 11(6), 652-659. https://doi.org/10.1108/WHATT-08-2019-0048

Saleem, Anum; Ellahi, Abida (2017) : Influence of electronic word of mouth on purchase intention of fashion products in social networking websites, Pakistan Journal of Commerce and Social Sciences (PJCSS), ISSN 2309-8619, Johar Education Society, Pakistan (JESPK), Lahore, Vol. 11, Iss. 2, pp. 597-622

Scott, D., C. D. Schewe, and D. G. Frederick 1978 A Multi-Brand/Multi-Attribute Model of Tourist

State Choice. Journal of Travel Research 17:23-29.

Semuel, H., \& Lianto, A. S. (2014).Analisis EWOM, Brand Image, Brand Trust dan Minat Beli Produk Smartphone di Surabaya. Jurnal Managemen Pemasaran, 47-54.

Shafira, A., \& Ferdinand, A. T. (2017).Analisis Pengaruh Celebrity Endorser dan Keinovatifan Produk Terhaap Keputusan Pembelian, Serta Citra Merek dan Nilai Utilitarian Sebagai Variabel Intervening. Diponegoro Journal of Management, 1-15.

Sheth, J. N. 1974 A Field Study of Attitude Structure and the Attitude-Behavior Relationship. In Models of Buyer Behavior, J. Sheth, ed. pp. 242-268. New York: Harper and Row.

Smith, D., Menon, S. and Sivakumar, K. (2005). Online Peer and Editorial Recommendations, Trust, and Choice in Virtual Markets.Journal of Interactive Marketing, 19(3), pp.15-37.

Sulthana, A.N, Vasantha, D.S (2019) Influence Of Electronic Word Of Mouth eWOM On Purchase Intention.International Journal of Scientific \& Technology Research, 8 (10),1-5.

Susilawati, S., Falefi, R., \& Purwoko, A. (2020). Impact of COVID-19's Pandemic on the Economy of Indonesia. Budapest International Research and Critics Institute (BIRCI-Journal): Humanities and Social Sciences, 3 (2), 1147-1156.

Tariq, M., Abbas, T., Abrar, M., \& Iqbal, A. (2017). EWOM and Brand Awareness Impact on Consumer Purchase Intention : Mediating Role of Brand Image. Pakistan Administrative Review, 84-102

Taungke, G.S \& Sunarti (2020). Pengaruh Celebrity Endorser dan Electronic Word of Mouth Terhadap Minat Beli dan Dampaknya Terhadap Keputusan Pembelian (Survei pada Konsumen Erigo di Akun Resmi Instagram Erigo). Jurnal Administrasi Bisnis, 78(1), 1-10

Teng, H. Y., \& Chen, C. Y. (2020).Enhancing celebrity fan-destination relationship in film-induced tourism: The effect of authenticity. Tourism Management Perspectives, 33 ([online]).

Till, B. D., \& Busler, M. (1998). Matching products with endorsers: Attractiveness versus expertise. Journal of Consumer Marketing, 15(6), 576-586.

Torlak, O., Ozkara, B., Tiltay, M., Cengiz, H. and Dulger, M. (2014). The Effect of Electronic Word of Mouth on Brand Image and Purchase Intention: An Application Concerning Cell Phone Brands for Youth Consumers in Turkey. Journal of Marketing Development and Competitiveness, 8(2), pp.61- 68

Trunfio, M., Campana, S., \& Magnelli, A. (2020).Measuring the impact of functional and experiential mixed reality elements on a museum visit. Current Issues in Tourism, 23(16), 1990-2008. https://doi.org/10.1080/13683500.2019. 1703914

Trusov, M., Bucklin, R., and Pauwels, K. (2009). Effects of word-of-mouth versus traditional marketing: Findings from an Internet social networking site. Journal of Marketing, 73(5), pp.90- 
102.

van der Veen, R., \& Song, H. (2010). Exploratory study of the measurement scales for the perceived image and advertising effectiveness of celebrity endorsers in a tourism context. Journal of Travel \& Tourism Marketing, 27(5), 460-473.

Vermeulen, I. E., \& Seegers, D. (2009). Tried and tested: The impact of online hotel reviews on consumer consideration. Tourism Manage Journal, 30(1), 123-127. http://dx.doi.org/10.1016/j.tourman.2008.04.008

Wibisono, A. F., \& Martini, E. (2016). Pengaruh Celebrity Endorsement Al Ghazali Pada Iklan Televisi Terhadap Brand Image Indomie Pada Penduduk Usia Muda di Kota Bandung. e-Proceeding of Management, 39-46.

Woomi, P. and Soocheong, J. (2008).Destination image and tourist attitude.Tourism Analysis, 13(4), pp.401-411.

Xia, L. and Bechwati, N. (2008). Word of mouse: The role of cognitive personalization in online consumer reviews. Journal of Interactive Advertising, 9(1), pp.108-128.

Yan, Wang (2018). Star power: the evolution of celebrity endorsement research. International Journal of Contemporary Hospitality Management, 30(1), 389-415

Zeithaml, V. A. (1988). Consumer Perceptions of Price, Quality and Value: A Means-End Model and Synthesis of Evidence. Journal of Marketing, 52(7), 2-22.

Zhang, H., Xiaoxiao, F., Cai, L. A., \& Lu, L. (2014). Destination image and tourist loyalty: a metaanalysis. Tourism Management, 40, 213e223

Zhu, F. and Zhang, X. (2010). Impact of Online Consumer Reviews on Sales: The Moderating Role of Product and Consumer Characteristics. Journal of Marketing, 74(2), pp.133-148. 